\title{
Beginnings of open-heart surgery in Gdansk - double role of the Pemco heart-lung machine and new facts about Dutch-Polish cooperation
}

\author{
Anna Paprocka-Lipińska \\ Department of Ethics, Medical University of Gdansk, Poland \\ Kardiochirurgia i Torakochirurgia Polska 2016; 13 (2): 189-191
}

\begin{abstract}
The first open-heart surgery in Gdansk took place in 1975. It was possible thanks to the gift of a Pemco extracorporeal circulation machine from the Netherlands to the Surgery Institute of the Medical Academy of Gdansk. The article presents additional, unpublished informations which enable a new interpretation of the previously known facts.

Key words: history of medicine, Pemco.
\end{abstract}

One of the more interesting issues connected with the work on the history of medicine is that no work in this area will ever be finished and the state of research will never be complete. Writing about historical facts assumes the readiness to find new information which may substantially change the earlier image of the events. Sometimes the information comes, as in this case, from unpublished materials and oral accounts of eyewitnesses.

In November last year, in Gdansk, there was a celebration commemorating the events which took place 40 years ago - the first open-heart surgery using extracorporeal circulation at the Medical Academy of Gdansk. On this occasion, it was possible to collect many facts from the recent past and describe them in a monograph, which emphasized the crucial moment of the first open-heart surgery on $29^{\text {th }}$ April 1975 [1]. It was repeatedly stressed that for many years the surgeons in Gdansk were supported by the cardiac surgery centre in Amsterdam, and it was thanks to its help that this unusual event could take place. However, the question what actually led to such support remained practically unanswered.

It is known that in 1972, by chance, Dr. Mirosława Narkiewicz from the Surgery Institute of the Medical Academy of Gdansk went for a one-year internship in cardiac surgery to the Onze Lieve Vrouwe Gasthuis (OLVG) Hospital instead of a surgeon from Warsaw. During that year, she participated in 124 open heart procedures under the supervision of one of the pioneers of cardiac surgery in the Netherlands -

\section{Streszczenie}

W 1975 r. odbyła się w Gdańsku pierwsza operacja na otwartym sercu. Stało się to możliwe dzięki temu, że Instytut Chirurgii Akademii Medycznej w Gdańsku otrzymał w darze z Holandii aparat do krążenia pozaustrojowego Pemco. W artykule opisano niepublikowane dotychczas informacje, dzięki którym możliwa staje się nowa interpretacja znanych faktów.

Słowa kluczowe: historia medycyny, płucoserce Pemco.

Prof. Anthon Gründeman [2]. While staying in Amsterdam, Dr. Narkiewicz was a frequent guest of the Gründeman family, which turned into a long-lasting friendship.

On coming back to Poland, Mirosława Narkiewicz began work aimed at the introduction of open-heart surgery at the Medical Academy of Gdansk. It was impossible to obtain the equipment necessary to perform open-heart surgery from the so-called central allocation, although in the report about the development of cardiac surgery in Poland from 1972 the centre in Gdansk was one of the five listed as centres needing to be developed and equipped according to the representatives of the Mother and Child Institute in Warsaw [3]. In the early seventies, relatively simple congenital heart defects were corrected in Gdansk using hypothermia under short circulatory arrest. The introduction of controlled hypothermia was made thanks to the great contribution of Ass. Prof. Karol Oppeln-Bronikowski, anaesthesiologist. He constructed a special suit which made it possible to gradually lower the deep body temperature to $30^{\circ} \mathrm{C}$ and safely stop the patient's circulation for a period of 2-6 minutes, enough to perform the key stage of the cardiac surgery $[4,5]$. The introduction of hypothermia was preceded by many years of research and practical experience gained during his stay in the Surgery Clinic of the Wilhelmina Gasthuis University Hospital in Amsterdam, led then by Prof. Ite Boerema [6]. Thanks to the use of hypothermia, the team of surgeons in Gdansk could perform different types of procedures, mostly atrial septum defect 
closure and pulmonary valvulotomy for stenosis in a way safe for the patients, without the use of extracorporeal circulation.

In May 1974, Gdansk held the $15^{\text {th }}$ Congress of the Thoracic and Vascular Section of the Association of Polish Surgeons. One of the speeches was a summary of the activities of the centre in Gdansk in the field of cardiac surgery [7]. One of the invited guests from abroad was Prof. Anthon Gründeman, who then came to Poland for the first time, with his wife and his secretary Gerda Kramer. Prof. Gründeman listened to the speeches with attention and asked many decision-making people why the centre did not perform open-heart surgery in children, if the cardiac diagnostics is so well developed and the team of surgeons and anaesthesiologists has, apart from enthusiasm, also adequate skills. His critical question "where is your heartlung machine?" could not be answered. The unmet needs, revealed during the conversations, emphasized the logistic difficulties, which were almost impossible to overcome without additional, external support.

Prof. Anthon Gründeman was one of the pioneers of Dutch cardiac surgery. He started to perform congenital heart surgery using extracorporeal circulation in the OLVG in 1957 [8]. It became possible after the purchase of a Pemco machine for extracorporeal circulation in the United States. In 1955, extracorporeal circulation systems were produced in three American centres, and they were substantially different in terms of the oxygenators used [9]. The extracorporeal circulation machine produced by Pemco Incorporated in Cleveland, Ohio, was equipped with a Kay-Cross rotating disc oxygenator, built by Jerome Kay and Frederick Cross [9]. It was possible to cover the high purchase costs thanks to a generous gift received by Prof. Anthon Gründeman from the Dutch family Brenninkmeijer. Before the finalization of the purchase, Prof. Gründeman went to Cleveland, to meet the president of Pemco, William Koteles, because he desired to have some changes made

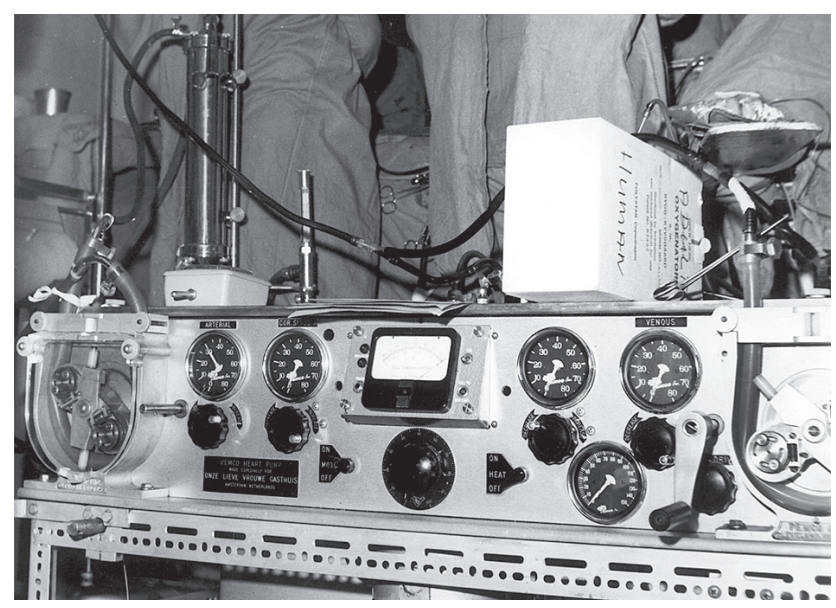

Fig. 1. Extracorporeal circulation machine by Pemco in the operating theatre of the Surgery Institute of the Medical Academy of Gdansk, 1975. Photograph from the archive of the Cardiac and Vascular Surgery Clinic of the Medical University of Gdansk in the structure of the machine. The proposal was accepted and a machine tailored for the OLVG Hospital was manufactured (Fig. 1).

Having returned from the conference in Gdansk in May 1974, Prof. Anthon Gründeman began intensive efforts aimed at helping in the most efficient way. The extracorporeal circulation machine by Pemco from the pioneer stage of the development of cardiac surgery in Amsterdam was in storage, but in good shape, because the equipment policy of the OLVG Hospital stated that the equipment had to be changed after ten years of use. Both the cardiac surgery operating room and the experimental centre used Sarns machines at that time [2]. Prof. Anthon Gründeman decided that Dr. Mirosława Narkiewicz should have the old OLVG Pemco to make open-heart surgery possible in Gdansk. The most important role in the preparation of the machine and completion of everything necessary to perform open-heart surgery procedures was played by Paul Gründeman, son of Prof. Anthon Gründeman, who then studied medicine but also worked as a perfusionist in the same OLVG heart centre since 1973. He re-assembled the Pemco machine to make it ready for use and knew everything about it. Later, he visited Gdansk many times, performed perfusions when Amsterdam surgeons came to operate there and actively participated in the training of the first perfusionists in the hospital in Gdansk: Dr. Bolesław Szołkowski and Dr. Andrzej Lipski. He also helped solve all technical problems related to the machine operation (Fig. 2). After some time of intensive use, the now "Gdansk" Pemco machine needed urgently maintenance but spare parts were not available. Fortunately, the same type of Pemco machine was purchased in the 1950s by another centre of Dutch cardiac surgery: St. Antonius Ziekenhuis Hospital in Utrecht. Dr. Sander Schaepkens van Riempst, head of that cardiac surgery unit and a personal friend of Prof. Anton Gründeman, allowed Paul Gründeman to take out the whole "interior" from their first extracorporeal circulation machine exhibited at that

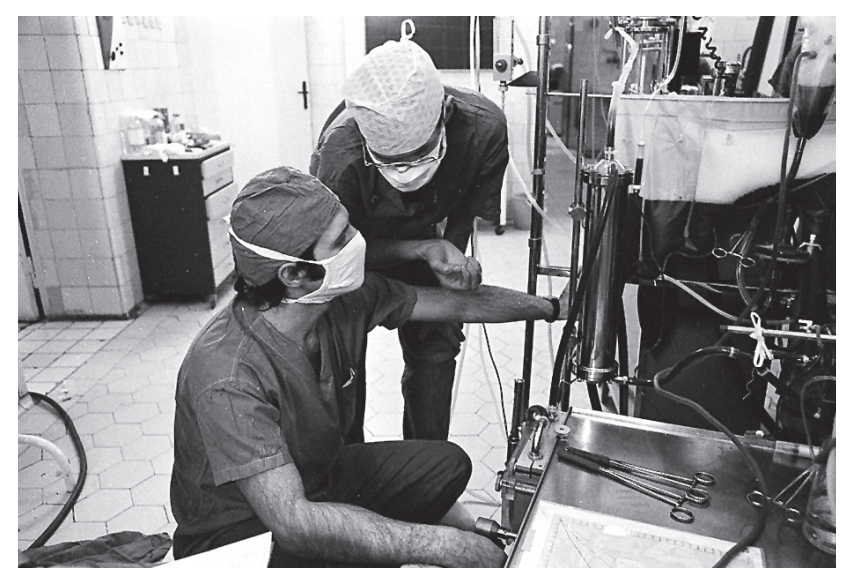

Fig. 2. Photograph from the operating theatre of the Surgery Institute of the Medical Academy of Gdansk, 1976. In the foreground, near the Pemco, is Andrzej Lipski, in the background is Paul Gründeman. The bubble oxygenator type on his left side is from RyggKyvsgaard. From the archive of P. Gründeman 
time in the Utrecht University museum; its empty case is still displayed. Thanks to this decision, the centre in Gdansk received not only a machine from Amsterdam but also many replacement parts from Utrecht's Antonius Hospital Pemco that were used by Paul Gründeman for its mandatory repairs in Gdansk.

The transport of the equipment to Poland and all related formalities were organised by the attache of the Polish Embassy in the Hague, Edward Chomicki. Further history is already known - the Pemco machine came on board the ship "Norwid" to Gdynia on $9^{\text {th }}$ December 1974. The first open heart surgery was performed in Gdansk on $29^{\text {th }}$ April 1975, after a series of trials on animals. It was a repair of a defect in the interatrial septum in an eight-year-old girl.

What is extremely important from the contemporary perspective and has not been expressed clearly until now, the same copy of the Pemco extracorporeal circulation machine played a double historical role in the initiation of open-heart surgery: in Amsterdam in 1957 and, almost 20 years later, in the Surgery Institute of the Medical Academy of Gdansk. It was more than an old, unused machine, and today we can surely say it was also more than a simple gift of a friend, although the fact of the long-lasting friendship between the families Gründeman and Narkiewicz must be emphasized. However, Prof. Anthon Gründeman could have limited his support by just training Gdansk surgeons in OLVG, by treating Gdansk children with heart defects as "guests" in Amsterdam and by donating redundant equipment. On the contrary, his firm believe was that such an approach would not result in a sustainable solution for Gdansk and would in the end limit the number of children getting a chance for adequate help. To lead Gdansk towards an independently operating heart centre of excellence, he paid attention to the need of training of every team member, the role of building cooperation between Gdansk and Amsterdam Hospital Board of Directors, and the whole logistic system related to open-heart surgery. Without doubt, it was something more than only a gift of equipment. Prof. Anthon Gründeman had a vision to share the whole of his pioneer experiences with the Polish team of relatively young doctors enthusiastic about their work. He was present and served with his experience at all key moments, such as performing the first implantations of artificial valves in Gdansk, in 1976. Thanks to such a complex solution, Prof. Anthon Gründeman and his team put into practice the principal rule of medical ethics - providing help for the severely ill in the best possible manner, using all knowledge and skills available.

\section{Disclosure}

Author reports no conflict of interest.

\section{References}

1. Paprocka-Lipińska A. Zarys dziejów gdańskiej kardiochirurgii w latach 1948 1987. Via Medica, Gdańsk 2015.

2. Narkiewicz M. Sprawozdanie z pobytu szkoleniowego w Amsterdamie. Pol Przegl Chir 1973, 45: 203-204.

3. Raport w sprawie rozwoju opieki kardiochirurgicznej w Polsce (24.01.1972). Archiwum Katedry i Kliniki Kardiochirurgii i Chirurgii Naczyniowej GUM-ed. Akta nieuporządkowane.

4. Oppeln-Bronikowski K. Powierzchniowa ciepłota ciała podczas operacji i wartość jej pomiarów w przebiegu uśpienia. Pol Tyg Lek 1960, 15: 342-346.

5. Oppeln-Bronikowski K. Zastosowanie gumowego skafandra w kontrolowanej hipotermii. Pol Przegl Chir 1963, 35: 303-306.

6. Archiwum GUM-ed. Akta osobowe Karol Oppeln-Bronikowski. sygn. 452/18.

7. Mlekodaj S, Narkiewicz M. Chirurgiczne leczenie wad serca w ośrodku gdań skim. In: Pamiętnik XV Zjazdu Sekcji Torakochirurgicznej i Chirurgów Naczyniowych Towarzystwa Chirurgów Polskich, Gdańsk 9-10.05.1974. 382-384.

8. Jonas Z, Oppeln-Bronikowski K, Narkiewicz M, Dymnicka-Małecka S, Przytarska B, Billewicz O, Sokół A. Wyniki chirurgicznego leczenia ubytku przegrody międzyprzedsionkowej i zastawkowego zwężenia tętnicy płucnej w hipotermii średniej. In: Pamiętnik XV Zjazdu Sekcji Torakochirurgicznej i Chirurgów Naczyniowych Towarzystwa Chirurgów Polskich, Gdańsk 9-10.05.1974. 402-405.

9. Stoney WS. Evolution of cardiopulmonary bypass. Circulation 2009; 119: 2844-2853. 